\title{
Developing English Learning Materials For Food And Beverage Service in Singaraja Hotel School
}

\author{
Gede Sudana Praptono \\ Pancasarjana Undiksha \\ Email: gsudana14@gmail.com \\ Putu Artini \\ Pascasarjana Undiksha \\ Email: putu.artini@pasca.undiksha.ac.id \\ I Wayan Suarnajaya \\ Pascasarjana Undiksha \\ Email: wayan.suarnajaya@pasca.undiksha.ac.id
}

\begin{abstract}
This research aimed at developing English learning material for food and beverage service in Singaraja Hotel School for D1 program. The research design followed 4D model. The steps of this study were: (1) Define,(2) Design, (3)Develop, and (3)Disseminate. There were two questionnaires employed in the research: (1) Needs analysis questionnaire (2) Expert judgment questionnaire. The materials needed are the English learning materials consisted of various activities and example for food and beverage service course. The activities of the materials were in the form of dialogues, detail explanation, illustration, and additional information related to food and beverage service course. Based on the data process, it was found that the score of the product quality was 256 . Based on the criteria made, it can be concluded that the quality of the product was categorized as good material. It means that the materials can be used in learning process.
\end{abstract}

Keywords: 4D, materials development, RnD, Need Analysis

\section{Introduction}

Indonesia is one of the countries that use tourism aspect as one of source income. Indonesian government promotes the tourism object in Indonesia seriously and makes great deals with some investors to build and develop tourism in Indonesia. Every province in Indonesia develops their tourism object in order to make good profit. Bali is one of provinces that use tourism as one of profit sources for developing Bali as a province. Bali is one of the favourite destinations in the world. It is because Bali has beautiful panorama and unique culture that make people excited know more about Bali.

As well as the development of Bali tourism is increasing, well quality of practitioner in tourism industry is also needed. Tourism practitioner needs to be able to give good service to the costumer. Good service can be done if the costumer and server understand each other, besides that, the server should have good quality in his or her position. In order to understand costumer's needs, the server needs to be able to use international language well, in this case, English.

Cousin et.al (2014) states that Food and Beverage Service is one area of tourism enterprise where English is used to support the success of the business. Food and Beverage (F\&B) services has a responsibility for maintaining high quality of food and beverage services, food costing, managing restaurants, bars, etc. In order to communicate and serve the costumer or guest, the F\&B servers need to be able to use language well, so that, there is no misunderstanding between the server and the costumer. In helping F\&B servers mastering good language, ESP practitioners need to develop appropriate materials based on students' need. Celce - Murcia (2001: 43) states that philosophically, all ESP learning materials should be tailored to the specific learning and language use needs on identified groups of students and also sensitive to the socio - cultural context in which these students will be using English. It means that appropriate language use and context should be suitable with the learners' field, in this case, F\&B service.

In developing an appropriate learning material for students, the materials should have some criteria such as the materials should have a good effect to the students' development. Good effect means that the materials can help and stimulate the students gaining knowledge and skill in the subject taught. Learning materials also have to deal with students' leaning style. The materials used must be authentic uses, which mean that the materials are relevant with students' job life in the future. The learning materials should give students opportunity to use language. It means that learning materials provide activities that allow students to expose the language. Learning materials should give the students examples and exercises needed in learning the language. 
Providing various topics and activities in learning material will help the students to gain language. In order to help students master English, the students need authentic topics as their basic knowledge to give good services to customers. The topics consist of detailed explanation and examples related to the topics given. Examples help students to understand topics given well.

Based on the preliminary observation that was conducted on April 24, 2019, it was found that there was no specific material for food and beverage service in Singaraja Hotel School. Preliminary observation was conducted by observing the materials used and asking the instructor about the obstacles found from the materials used. It was found that the instructor used unstructured material gained from online source in learning process. The materials cannot provide various activities and examples. Therefore, English learning material is needed to be developed.

Based on Tomlinson (1998), the material development is everything made by people (the writers, the teachers, or the learners) to give information and provide experience of using language, which is designed to promote language learning. In relation with that statement, Tomlinson (2011) states materials for language learning refer to the things that help students to learn the language. The materials include books, videos, graded readers, flash cards, game, websites, and mobile phone interactions, though inevitably, and much of the literature focuses on printed materials. Material is one thing that is needed to support the learning activities of the learners.

In developing the materials, need analysis is the basis step that should be done. Need analysis is used to collect data of the students need. By knowing the students need, it can be used as basis information to develop the materials. Celce - Murcia (2001) claims that need analysis is a set of procedure of determining the communicative needs of the learner. This statement is also quite similar with Richards (2001) who states that need analysis is a procedure used to collect information about learners' needs. It means that need analysis is an activity that is done to know and understand what learners need for their learning goal.

In developing the materials, 4D model that is proposed by S. Thagarajan and Doroty S. Sammel (1974) is used. The 4D model consists of four steps, they are define, design, develop, and disseminate. There are four steps of 4D model, they are "define", "design", "develop", and "disseminate". "Define" is the process to investigate the problems and the characteristics of the students as the users of the product. The aims of "define" are to understand the condition and the situation as the parts of the planning of the process of designing a product. "The design step" was equipped with the explanation of each component, how learning material was developed should be inserted in the design. After the draft was made, the next stage was to develop the draft into product. "Develop" step is the step where the quality of the product measured and developed, it was necessary to modify the prototype instructional materials. Although there were many things that have been produced from the "define" stage, the results should be considered an initial version of the instructional materials which had to be modified before it could become an effective final version. Disseminate step refers to the packaging and publishing the product.

\section{Methodology}

This study conducted in Food and Beverage service Department in Singaraja Hotel School. Singaraja Hotel School was chosen because the institution did not have specific material for English learning materials, so that the researcher did the research in Singaraja Hotel School

The subjects of this study are students of first diploma (D1) and teacher of Singaraja Hotel School. There are 22 students in food and beverage service department of Singaraja Hotel School. There is one instructor who teaches English for food and beverage service. The object of this study is developing English materials for Food and Beverage service students because they did not have specific learning materials for food and beverage service course.

In gaining a valid and reliable data, a number of instruments were designed and used based on the stages in the study design. There were three instruments used in obtaining the data such as interview guide, questionnaire and document study. Kinds of instruments that were used in this study were instrument for identifying students' needs and developing syllabus and instruments for the validation process. The instruments were used to collect the data related to the students' needs. The instrument used was the questionnaire.

There were 23 questions given to the 22 students of Singaraja Hotel School. The questionnaires were also given to the instructor and stakeholder of Singaraja Hotel School in order to obtain various data in developing the learning materials. It was used to identify students' needs in developing English learning materials for Food and Beverage service students.

In order to measure the product quality, there were a number of instruments that were used to confirm the validation of the materials. The development of the instruments refers to the theories or review about developing English material selection. The kind of instrument that was used to measure the product was the questionnaire evaluation. There were 31 items that were used to measure the quality of the product. These items used criteria proposed by Litz (2005). The questionnaires were given to the two expert judges. 


\section{The Research Findings}

Based on the questionnaires given to the students, instructor, and stakeholder, the materials that were needed for the students are as follows.

1. The topics should be more specific for Food and beverage services

2. The material should contain language expressions.

3. The topics needed should be specific for Food and Beverage services Students

4. The most skill needed by the students is speaking skill

5. The material should consist of information and explanation

The materials were designed based on the need analysis made. After analyzing the students' need, the researcher designed the product by creating draft of the product and determining the units of the English learning materials. There were eleven units in the book, they are handling reservation, setting table, welcoming and seating the guest, giving menu, taking order, serving, clearing table, handling complaint, handling payment, job description, the good waiter.

In order to know the quality of the product, the researcher did expert judgment. The product is measured by two experts by fill in the questionnaire given. The questionnaire consisted of scale and the scale is from $1-5$. The data were analysed by using Candiasa (2010).

Table 1. Formula

\begin{tabular}{ll}
\hline Score & Criteria \\
\hline $\mathrm{Mi}+1,5 \mathrm{Sdi} s / \mathrm{d} \mathrm{Mi}+3 \mathrm{Sdi}$ & Sangat Baik \\
$\mathrm{Mi}+0,5 \mathrm{Sdi} \mathrm{s} / \mathrm{d} \mathrm{Mi}+1,5 \mathrm{Sdi}$ & Baik \\
$\mathrm{Mi}-0,5 \mathrm{Sdi}$ s/d $\mathrm{Mi}+0,5 \mathrm{Sdi}$ & Cukup \\
$\mathrm{Mi}-1,5 \mathrm{Sdi}$ s/d Mi-0,5 Sdi & Kurang \\
$\mathrm{Mi}-3 \mathrm{Sdi} \mathrm{s} / \mathrm{d} \mathrm{Mi}-1,5 \mathrm{Sdi}$ & Sangat Kurang \\
\hline
\end{tabular}

Candiasa (2010) formula.

The result of the data analysis, it was found that the first expert gave 136 points and the total points that was given by second expert was 142 points. The total point given by both experts was 278 points. Based on the data process, it found that the score of product was 256. Based on the criteria made, it can be conclude that the quality of the product is good material. Good materials mean that the materials were ready to use in teaching and learning process.

\section{Conclusion}

This study has weaknesses in measuring the product, that is, the product should be implemented and tested to the students to know whether the product can be applied or not. In fact, to know the quality of the product, the researcher only uses the validation given by experts judges because the limitation of time. For the future research, the process of measure the quality of the product was expected until the implementation of the product.

The researcher suggests the instructor to use the book because the book can assist the students in gaining the knowledge. This book cannot be used for food and beverage service class but it also can be used by people who want to learn food and beverage services. This book consists of some topics that can be used as a resource of gaining the knowledge.

The researcher suggests the students to use the book because it could help them to obtain the information needed. The book provided some additional information that can give the students the new knowledge related to the food and beverage service.

\section{Reference}

Cousin, Jhon.,D.Lillicarp.,Suzanne, weekes.(2014). Food and beverage service. 9th edition.England: British Library

Litz, D.A.R (2005). Text Book Evaluation and ELT Management: a South Korea Case Study.Asian EFL Journal. Retrieved on June 10, 2018 at http://docslide.us/documents/litz-thesis.html.

Murcia, M. C. (2001). Teaching English as a Second or Foreign Language. Third Edition. Musschusettes. New Burry House Publisher. Inc Rowley.

Richard. J.C. (2001). Curriculum Development in Language Teaching. USA: Cambridge

S. Thagarajan, Dorothy S. Semmel. (1974) Instructional Development For Training Teachers of A Extional Children A Sourcebook. Bloomington Indiana,Indiana University 
Tomlinson. B. (1998). Materials Development in Language Teaching. United Kingdom: Cambridge University Press.

Tomlinson. B. (2011). Material Development In Language Teaching; Second Edition. United kingdom: Cambridge University Press 